\title{
Review Article \\ Racial Threat Theory: Assessing the Evidence, Requesting Redesign
}

\author{
Cindy Brooks Dollar \\ Department of Sociology, The University of North Carolina at Greensboro, 337 Frank Porter Graham Building, \\ P.O. Box 26170, Greensboro, NC 27402-6170, USA \\ Correspondence should be addressed to Cindy Brooks Dollar; cbdollar@uncg.edu
}

Received 3 April 2014; Accepted 22 June 2014; Published 9 July 2014

Academic Editor: Augustine Joseph Kposowa

Copyright (C) 2014 Cindy Brooks Dollar. This is an open access article distributed under the Creative Commons Attribution License, which permits unrestricted use, distribution, and reproduction in any medium, provided the original work is properly cited.

Racial threat theory was developed as a way to explain how population composition influences discriminatory social control practices and has become one of the most acknowledged frameworks for explaining racial disparity in criminal justice outcomes. This paper provides a thorough review of racial threat theory and empirical assessments of the theory and demonstrates that while scholars often cite inconsistent support for the theory, empirical discrepancies may be due to insufficient attention to the conceptual complexity of racial threat. I organize and present the following review around 4 forms of state-sanctioned control mechanisms: police expenditures, arrests, sentencing, and capital punishment. Arguing that the pervasiveness of racialization in state controls warrants continued inquiry, I provide suggestions for future scholarship that will help us develop enhanced understanding of how racial threat may be operating.

\section{Introduction}

Racial-ethnic inequality in the criminal justice system is well-documented and has gained widespread attention in the sociological, criminological, and legal literature. Blalock's [1] racial threat theory is arguably the most popular explanation for such differential treatment. Relying on a racebased conflict approach in explaining social control practices, Blalock [1] views social organization as being rooted in racialized competition whereby race and ethnic groups are in constant struggles over valued resources. This paper begins by providing a review of racial threat theory and the literature examining this theory. By examining the literature by social control form, it is suggested that patterned theoretical support may be associated with how publically transparent the form of social control is. That is, racial threat effects may be diffused when the social control mechanism is less influenced by direct public influence. I conclude by suggesting ways in which future research can further explicate the ways racial threat operates to deny minorities from acquiring equal access to resources and opportunities.

\section{Racial Threat Theory}

Race is a significant element in the creation of US social organization and continues to shape the type and extent of state-sanctioned control practices. Following the civil rights movement of the 1960s, social scientists began using critical perspectives to scrutinize racialized outcomes. Calls for examinations of internal colonialism [2-4], institutionalized racism [5], persistent racial tensions [6], and racialized ideologies [7] became more common.

Blalock's [1] racial threat theory is perhaps one of the most frequently examined explanations for racial disparity in criminal justice outcomes. Racial threat theory proposes that racialization occurs when Whites use their disproportionate power to implement state-control over minorities and, in the face of a growing minority population, encourage more rigorous, racialized practices in order to protect their existing power and privileges [1].

Blalock [1] posits three distinct forms of racial threateconomic threat, political threat, and symbolic threat. Economic threat develops when White workers view minorities 
as being threatening to job availability, job stability, and wages. Political threat emerges from White elites' fear of losing political power and symbolic threat surfaces when Whites, regardless of social class, perceive non-Whites as being essentially linked to crime or other "deviant" behavior. The theory predicts that each type of threat encourages White support for state-sanctioned social control practices as a means to reproduce White hegemonic power.

In his original formulation of the theory, Blalock [1] emphasizes the effects of economic and political threat on producing support and implementation of repressive state control mechanisms. He argues that the size of minority population provides a necessary indicator of macrostructural threats. For this reason, most investigations of racial threat rely on the percent of relative minority population as the primary or sole measure of threat. Blalock [1, page 28] notes, however, that his choice to deemphasize symbolic and microlevel threat effects may need to be reconsidered if such processes were empirically demonstrated to clarify the link between macrolevel phenomenon and inequitable social control practices.

Investigations of Blalock's racial threat theory have been extensive and examine various mechanisms of formal state control. Although the theory is often said to suffer from conflicting support (e.g., $[8,9])$, when reviewing the literature by particular phases of state control, some consistencies are revealed. For example, research works investigating the effects of minority population size and other macrostructural indicators of threat on increased policing expenditures and state executions are generally supportive of racial threat hypotheses, but findings related to arrests and imprisonment produce contradictory conclusions. Below I review the literature examining racial threat theory by particular statesanctioned control phases. By organizing the review in this manner, I expose several patterns, including similarities and differences, in research findings and necessary inquires for future research.

\section{Empirical Research on Racial Threat Effects}

3.1. Police Expenditures. Examinations of police expenditures are employed to measure the size and strength of the police force. These measures are associated with the response to perceived threat because it is assumed that police organizations are utilized to combat various forms of conflict [10], including economic, political, and symbolic threat. Most research works investigating causes of police expenditures rely on the percent of relative minority population as a measure of threat and find relatively strong support for Blalock's hypotheses. Huff and Stahura's [11] investigation of suburban areas in the US, for example, finds that the percentage of Black residents is a statistically significant predictor of the number of police officers employed even when violent and property crime rates remain stable. Similar conclusions are reached in examinations of US urban areas. Using city-level data, Jackson and Carroll [12] conclude that the relative minority population size is positively associated with policing expenditures in 90 cities outside of the South (see [13] for similar findings).

Cross-national analyses provide further support for the theory. Kent and Jacobs [14] note that the US is the only nation of 11 developed nations that show a significant relationship between increased minority population and police size, but economic inequality-operationalized as the Gini index-and crime rates influence the size of the police force in all nations surveyed. This finding highlights the significance of Blalock's argument about the unique racialized history of the United States. Further exploring the spatial relevance of racial threat, Kent and Jacobs [15] find that police force size was contingent on the interaction between minority population size and racial segregation level in US cities. Specifically, the authors reveal a negative relationship between cities with a high proportion of segregated minorities and police force size.

Given the increased migration in recent years, recent research extends racial threat analyses by investigating how the relative size and concentration of Hispanic populations influence police expenditures. This research suggests that support for increases in criminal justice expenditures varies by the minority group being examined. Holmes et al. [16] find that percentage of Hispanics has a minimal influence on resource allocation as compared to percentage of Blacks. While percent Black has a strong, positive association with police resource allocation, percent Hispanic had a weak, positive relationship. This study notes, however, that proximity to a US-Mexico border is an important consideration in predicting increased police expenditures. Specifically, states closer to a border have higher police expenditures.

This recent work suggests that proximity to minorities and racialized fear about racial-ethnic groups' may influence perceptions of racial threat. Some studies do conclude, in fact, that the increased expenditures have less to do with the size of the racial-ethnic minority population and more to do with whether perceptions of minority groups are associated with crime [17]. Linking racialized fear to police funding, Barkan and Cohn [18] conclude that racial prejudice is positively associated with increased criminal justice expenditures. Stults and Baumer [19] also find that Whites' perceptions of racialized economic threat and fear of crime equally predict variation in police force size, and they further note that the downward slope of the threat-control relationship is not dependent on minorities being the numerical majority. Rather, minority populations are able to mobilize resources when they number approximately 25 to 30 percent of the population, which allows them sway political decisions about how control practices are employed ([19]; also see [15]).

3.2. Arrests. The literature investigating racial threat effects on arrest rates has produced mixed conclusions. Liska and Chamlin's [20] analysis of US cities reveals that the size of non-White population increases total arrest rates but has no influence on non-White arrests patterns (see [21] for similar findings). More recent scholarship also concludes null findings in investigating economic and political threat on Black arrests. Stolzenberg et al. [22], for example, find 
that neither the percentage of Blacks nor the presence of competition in an area is related to an increased probability of Black arrests.

Some scholars argue that the lack of theoretical support may stem from researchers relying too heavily on crude measures of racial threat (i.e., minority population size). To this end, researchers employ more complex and varied measures of racial threat to explain the empirical reality of race-based differences in arrests. Parker et al. [9] conceptualize and measure racial threat using a variety of dimensions. In addition to the size of the Black population, they operationalize economic competition using measures of racial inequality and Black migration patterns and examine the independent effects of concentrated minority disadvantage and racial residential segregation on arrests. Although the results conclude a direct relationship between racial threat and Black arrest rates, the effects do not operate in the theoretically specified direction. Rather, Parker et al. [9] find that the relative size of Black population is negatively associated with arrest rates and interpret these findings as supporting the benign neglect hypothesis, which argues that state controls weaken in areas with a large minority population because of the decreased risk of White victimization [20]. These findings raise further questions about how threat influences race-specific arrest levels.

3.3. Sentencing. Empirical investigations of race effects in sentencing outcomes are numerous. Although many studies clearly demonstrate racial differences in sentencing net of legal factors, the effect of racial threat on sentencing decisions is far from clear. For example, although Ulmer and Johnson [23] find a positive relationship between minority population size and length of imprisonment among Black and Hispanic defendants, there was no association between minority population size and decisions about in-out incarceration decisions. Investigations of sentencing practices of Hispanic defendants in federal courts provide further challenge to racial threat postulations. Feldmeyer and Ulmer [24] conclude that Hispanic defendants receive more severe sentences when they make up an extremely small proportion of the population and more lenient sentences when they comprise larger proportions of the populations.

Recognizing that sentencing involves multifaceted legal assessments, researchers now examine various aspects of sentencing decisions. Johnson et al.s [25] investigation of downward departures in federal district courts concludes that Black and Hispanic defendants are far less likely to receive downward departures in districts that comprise a large proportion of Black and Hispanic residents, although various other factors including caseloads are also important predictors. Additionally, researchers note that habitual offender designations are more commonly assigned to Black and Latino defendants as compared to Whites. In an analysis of female offenders, Crawford [26] finds that Black female defendants are more often sentenced as habitual offenders in areas with a relatively large percent of African-Americans; however such race effect on habitual status assignment is not always positively associated with the percent Black population. Crawford et al. [27], for example, discover that male minority defendants are more likely to be sentenced as a habitual offender in areas marked with relatively small Black population.

The above-reviewed studies measure racial threat by relying largely (if not solely) on the minority population size. However, in a recent investigation, Caravelis et al. [28] explain disparate sentencing by focusing on increasing racial-ethnic minority populations. Citing Blalock [1], they note that static indicators of percent minority population may be less threatening than growing minority populations. Their findings support this interpretation, and they conclude that Blacks and Latinos are significantly more likely to be designated as a habitual offender than Whites in areas where the populations of these minority groups are rising but are not statically large.

Recognizing the need to expand measures of threat beyond the objective measure of non-White population size, researchers have started investigating the link between symbolic or perceptual threat and sentencing outcomes. In fact, there is some suggestion that judicial actors associate minority populations with criminal activity and implicitly acknowledge that criminal responses are driven partially by minority population size. Bridges et al. [29] interviews with law enforcement and court officials, for example, reveal that officials perceive minority populations as a threat to community order and thus viewed harsher punishment of minorities as legally justifiable. Chiricos et al. [30] telephone survey of a national random sample of households also finds that persons are more likely to voice support for harsh responses to crime when crime was perceived as a "Black phenomenon." Taken together, these findings suggest that indicators of symbolic threat may clarify the processes by which racialized control practices are enforced.

3.4. Capital Punishment. Although investigations on this topic are relatively scarce, research examining the link between racial threat and capital punishment has been largely supportive of the theory. Jacobs and Carmichael's [31] statelevel analysis across 3 time periods-1970-71, 1980-81, and 1990-91-reveals that the percent Black population and the incidence of a death sentence are positively related; that is, states with higher proportions of Blacks are more likely to have imposed a death sentence (also see [32]). Using a sociohistorical approach, Jacobs et al. [33] investigate lynching and state-sanctioned capital punishment sentences from 1889 to 1992. Revealing a link between fatal vigilantism used to control African American ex-slaves and continued support for race-specific state-sanctioned death sentences, the authors find that recent death sentences were more likely when the state contained a large proportion of minorities and a history of vigilante violence. Finally, conducting a multilevel model that nested individual data within residing counties, Baumer et al. [34] find that persons living in areas with a relatively high minority population are more likely to support the death penalty than persons living in areas with relatively low minority populations, net of various individual-level attributes, homicide rate, and areal socioeconomic factors. 


\section{Requesting Redesign: Directions for Future Research}

A critical examination of previous work allows scholars to better understand the differential support for threat-induced state control across adjudication phase. In the case of racial threat, the overall inconsistency in support may be due to issues of model specification. Below I review three specific issues. First, I discuss the need to explore how symbolic threat mediates the relationship between economic and political threat and state-sanctioned social control practices. Second, I review the varying hypothesized effects of economic inequality on economic and political threat. Finally, I note the need for future studies to examine whether the implementation of formal social control mechanisms minimizes threat as proposed by Blalock [1].

4.1. Explicating Intervening Processes. As mentioned earlier, Blalock [1] acknowledges that microlevel processes may need to be explored in order to explain the link between macrostructural competition and discriminatory social control practices. Some empirical work has provided compelling evidence that fear-inducing prejudicial attitudes mediate the link between minority population size and support for racialized social control practices [18, 29, 30, 35-37], and evidence indicates that minorities are punished more severely for crimes that Whites perceive to be more socially threatening, such as sex offenses, drug offenses, and certain property crimes $[27,28,38,39]$.

King and Wheelock's [40] investigation of how population composition and perceptions of minority economic threat predict racialized punitive attitudes is especially enlightening. Using Census data to determine changes in the relative size of minority population and county unemployment rate and survey data on adult perceptions of minority threat to jobs and welfare, the authors find that when Whites perceive greater threat, they are more willing to apply punitive punishment to criminal offenders, especially to Black criminal offenders.

Although scholarship is beginning to uncover the link between minority population size and the endorsement of race-based policies, we still need to identify the mechanisms by which attitudes about racialized punishment result in differential treatment by race. Thus, future research would benefit by further explicating how individual-level processes, such as prejudice and resentment, intervene between structural competition and state-sanctioned social control.

Sociologists have previously argued that prejudice is difficult to measure, especially given the covert and subtle ways that race-based notions are currently expressed. Over the last decade, however, scholars have developed imaginative methods by which to identify racial biases (e.g., [41-45]). Implementing these techniques, including covert interviews, storyline analysis, and audit studies, into examinations racial threat could provide critical information about racialized attitudes. Because race-based prejudice is most precisely identified using individual-level data and calculating macrostructural threat measures requires areal data, multilevel modeling is likely necessary to best explicate potential intervening processes.

4.2. Economic Inequality and Racial Threat. Blalock [1] hypothesizes that the relationship between macrostructural threat and repressive social control is curvilinear, although the downward slope is hypothesized to result from varying levels of economic inequality [8]. When discussing economic threat, Blalock [1, pages 154, 168] argues that privatized employer control can overtake state control. In other words, state-sanctioned controls may be less racialized when employer controls "effectively" minimize threat. This argument indicates that, in seeking to increase profits, employers hire non-White workers, who they pay a lower wage and fewer economic benefits, to replace White workers. Such competition for job attainment, job stability, sufficient wages, and other limited economic resources causes tension between racial-ethnic groups $[46,47]$, which produces racialized threat. Nonetheless, because employers provide minorities with fewer economic benefits, economic inequality between Whites and non-Whites remains high; thus, while job competition produces economic threat, interracial economic inequality remains relatively extensive [8]. In contrast, Blalock posits that political threat is greatest when economic inequality is low because low economic inequality indicates that minorities have gained financial resources more on par with Whites, which allows for greater access to political resources.

Blalock [1] hypothesizes, then, that economic inequality is positively associated with economic threat and negatively associated with political threat. Moreover, he implies that the type of threat experienced is contingent on levels of racebased economic inequality. Many previous investigations, however, include measures of economic inequality in statistical models as controls without taking into account the varying effects of economic inequality. In trying to settle empirical inconsistencies in other topical areas, scholars have discussed the importance of specifying countervailing relationships in regression models (e.g., $[48,49])$. In essence, these scholars argue that models should estimate oppositional forces so as not to risk cross-canceling effects. While economic inequality is not hypothesized to mediate the relationship between threat and control, these earlier works provide some insight for future racial threat studies.

Racial threat research would benefit from examining if (how) the extent of economic inequality uniquely moderates economic and political threat effects. Including interaction terms that combine threat and economic inequality measures into statistical models will indicate economic inequality's contingent effect. Alternatively, researchers could create two subsamples-one containing areas with high economic inequality and another containing areas with low economic inequality. By conducting regression analyses separately across the subsamples, the researcher can determine the isolated effect of varying levels of economic inequality. If the hypotheses proposed by Blalock [1] are validated, we would expect that economic threat is more common in areas with relatively high levels of economic inequality, while political 
threat is more likely in areas with relatively low levels of economic inequality.

4.3. Formal Social Control as Threat Minimization. A comprehensive review of the literature reveals that measurement about the extent to which social control practices actually minimize minority threat remains unexamined. In fact, I am unaware of any study that examines whether repressive social control practices "successfully" minimize minority threat. As described previously, racial threat theory predicts that (1) an increase in minority population size results in the potential for minority mobilization; (2) such potential results in Whites' endorsement and exercise of state control measures, which (3) decreases minority threat. This last proposition has yet to be examined in extant assessments of the theory; therefore, the literature has not clearly established if social control measures actually decrease minority threat. If Blalock's theory is accurate, Whites comfort in their dominant position would be restored after desired criminal justice policies are initiated. Establishing such a minimization effect is important in fully assessing Blalock's hypotheses.

\section{Conclusion}

Blalock's [1] formulation of racial threat theory provides an explanation of the observed racial discrepancies in stateresponses to crime by fundamentally emphasizing how racial composition influences discriminatory control practices. The theory has been subjected to numerous empirical examinations and is often considered as having conflicting support. However, when separating investigations by particular control mechanisms, some consistencies are revealed. Specifically, research works on criminal justice expenditures and capital punishment decisions seem largely supportive of Blalock's [1] fundamental theoretical model, which largely emphasizes minority population size as an indicator of threat. Threat effects on arrests and sentencing appear to be more complex and variable, but recent research in these areas suggests that more elaborate conceptualizations and measurements of racial threat may better predict racialized control practices.

Understanding patterns of theoretical support (and the lack thereof) by each criminal justice phase is crucial to developing intellectual knowledge that assists in creating fair policies and law. This review indicates that racial threat effects may be related to how publicly transparent the "justice" event is. For example, since arrests and sentencing are largely handled by organizational entities and subject to some bureaucratic rules, the direct influence of racial threat may be weaker, veiled, or otherwise abstracted in these phases, which results in somewhat inconsistent research findings. However, budget allocation and lethal sentencing, which are commonly the topic of political campaigning, may be subjected to greater public influence. Notwithstanding this argument, all punishment is political $[50,51]$, and given prior findings about the hydraulic effect of punishment practices [52], understanding where racialized threat may be more directly operating is crucial to elucidating the causes of differential treatment. Consequently, despite the significant amount of research on racial threat theory, additional research is needed to explain how racialized threat influences state-sanctioned control practices.

In this paper, I argue that future research would benefit by focusing on three primary issues. First, although some research suggests that racialized prejudice mediates the relationship between minority population size and race-based repressive control practices, we need additional investigations to clarify the apparent mediation effect. Second, Blalock's theory implies that economic inequality may produce countervailing forces on social control practices, so future research should strive to accurately identify the potential for such effects in statistical modeling. Third, in order to examine the concluding supposition of Blalock's theory, scholars should undertake examinations of how (if) racialized threat is minimized after employing race-based practices. Racial differences in social control practices are persistent, and specifying the processes by which such differences operate is an important part of revealing fissures in democratic ideals.

\section{Conflict of Interests}

The author declares that there is no conflict of interests regarding the publication of this paper.

\section{References}

[1] H. M. Blalock, Toward A Theory of Minority-Group Relations, John Wiley and Sons, New York, NY, USA, 1967.

[2] R. Blauner, "Internal colonialism and ghetto revolt," Social Problems, vol. 16, no. 4, pp. 393-408, 1969.

[3] R. Blauner, Racial Oppression in America, Harper \& Row, New York, NY, USA, 1972.

[4] M. Barrera, Race and Class in the Southwest, University of Notre Dame Press, South Bend, Ind, USA, 1979.

[5] D. Wellman, Portraits of White Racism, Cambridge University Press, New York, NY, USA, 1977.

[6] H. Blumer, "Industrialisation and race relations," in Industrialisation and Race Relations, G. Hunter, Ed., pp. 220-253, Oxford University Press, London, UK, 1965.

[7] M. Omi and H. Winant, Racial Formation in the United States: From the 1960s to the 1990s, Routledge, New York, NY, USA, 1986.

[8] D. Eitle, S. J. D’Alessio, and L. Stolzenberg, "Racial threat and social control: A test of the political, economic, and threat of black crime hypotheses," Social Forces, vol. 81, no. 2, pp. 557576, 2002.

[9] K. F. Parker, B. J. Stults, and S. K. Rice, "Racial threat, concentrated disadvantage and social control: considering the macrolevel sources of variation in arrests," Criminology, vol. 43, no. 4 , pp. 1111-1134, 2005.

[10] A. Turk, Criminality and the Legal Order, Rand McNally, Chicago, Ill, USA, 1969.

[11] C. R. Huff and J. M. Stahura, "Police employment and suburban crime," Criminology, vol. 17, no. 4, pp. 461-470, 1980.

[12] P. I. Jackson and L. Carroll, "Race and the war on crime: the sociopolitical determinants of municipal police expenditures in 90 Non-Southern U.S. cities," American Sociological Review, vol. 46, pp. 290-305, 1981. 
[13] P. Jackson, Minority Group Threat, Crime, and Policing, Preager, New York, NY, USA, 1989.

[14] S. L. Kent and D. Jacobs, "Social divisions and coercive control in advanced Societies: law enforcement strength in eleven nations from 1975 to 1994," Social Problems, vol. 51, no. 3, pp. 343-361, 2004.

[15] S. L. Kent and D. Jacobs, "Minority threat and police strength from 1980 to 2000: a fixed-effects analysis of nonlinear and interactive effects in large U.S. cities," Criminology, vol. 43, no. 3, pp. 731-760, 2005.

[16] M. D. Holmes, B. W. Smith, A. B. Freng, and E. A. Muñoz, "Minority threat, crime control, and police resource allocation in the Southwestern United States," Crime and Delinquency, vol. 54, no. 1, pp. 128-152, 2008.

[17] K. Welch, A. A. Payne, T. Chiricos, and M. Gertz, "The typification of Hispanics as criminals and support for punitive crime control policies," Social Science Research, vol. 40, no. 3, pp. 822840, 2011.

[18] S. E. Barkan and S. F. Cohn, "Why whites favor spending more money to fight crime: the role of racial prejudice," Social Problems, vol. 52, no. 2, pp. 300-314, 2005.

[19] B. J. Stults and E. P. Baumer, "Racial context and police force size: evaluating the empirical validity of the minority threat perspective," The American Journal of Sociology, vol. 113, no. 2, pp. 507-546, 2007.

[20] A. E. Liska and M. B. Chamlin, "Social structure and crime control among macrosocial units," American Journal of Sociology, vol. 90, no. 2, pp. 383-395, 1984.

[21] Chamlin M. B. and A. E. Liska, "Social structure and crime control revisited: the declining significance of intergroup threat," in Social Threat and Social Control, A. E. Liska, Ed., pp. 103-112, State University of New York Press, Albany, NY, USA, 1992.

[22] L. Stolzenberg, S. J. D’Alessio, and D. Eitle, "A multilevel test of racial threat theory," Criminology, vol. 42, no. 3, pp. 673-698, 2004.

[23] J. T. Ulmer and B. Johnson, "Sentencing in context: a multilevel analysis," Criminology, vol. 42, no. 1, pp. 137-178, 2004.

[24] B. Feldmeyer and J. T. Ulmer, "Racial/ethnic threat and federal sentencing," Journal of Research in Crime and Delinquency, vol. 48, no. 2, pp. 238-270, 2011.

[25] B. D. Johnson, J. T. Ulmer, and J. H. Kramer, "The social context of guidelines circumvention: the case of federal district courts," Criminology, vol. 46, no. 3, pp. 737-783, 2008.

[26] C. Crawford, "Gender, race, and habitual offender sentencing in Florida," Criminology, vol. 38, no. 1, pp. 263-280, 2000.

[27] C. Crawford, T. Chiricos, and G. Kleck, "Race, racial threat, and sentencing of habitual offenders," Criminology, vol. 36, no. 3, pp. 481-511, 1998.

[28] C. Caravelis, T. Chiricos, and W. Bales, "Static and dynamic indicators of minority threat in sentencing outcomes: a multilevel analysis," Journal of Quantitative Criminology, vol. 27, no. 4, pp. 405-425, 2011.

[29] G. S. Bridges, R. D. Crutchfield, and E. Simpson, "Crime, social structure and criminal punishment: white and non-white rates of imprisonment," Social Problems, vol. 34, no. 4, pp. 345-361, 1987.

[30] T. Chiricos, K. Welch, and M. Gertz, "Racial typification of crime and support for punitive measures," Criminology, vol. 42, no. 2, pp. 358-390, 2004.

[31] D. Jacobs and J. T. Carmichael, "The political sociology of the death penalty," The American Sociological Review, vol. 67, no. 1, pp. 109-131, 2002.
[32] D. Jacobs and J. T. Carmichael, "Ideology, social threat, and the death sentence: capital sentences across time and space," Social Forces, vol. 83, no. 1, pp. 249-278, 2004.

[33] D. Jacobs, J. T. Carmichael, and S. L. Kent, "Vigilantism, current racial threat, and death sentences," The American Sociological Review, vol. 70, no. 4, pp. 656-677, 2005.

[34] E. P. Baumer, S. F. Messner, and R. Rosenfeld, "Explaining spatial variation in support for capital punishment: a multilevel analysis," The American Journal of Sociology, vol. 108, no. 4, pp. 844-875, 2003.

[35] T. Chiricos, M. Hogan, and M. Gertz, "Racial composition of neighborhood and fear of crime," Criminology, vol. 35, no. 1, pp. 107-128, 1997.

[36] L. Quillian, "Group threat and regional change in attitudes toward African-Americans," American Journal of Sociology, vol. 102, no. 3, pp. 816-860, 1996.

[37] L. Quillian and D. Pager, "Black neighbors, higher crime? The role of racial stereotypes in evaluations of neighborhood crime," The American Journal of Sociology, vol. 107, no. 3, pp. 717-767, 2001.

[38] R. J. Sampson and J. H. Laub, "Structural variations in Juvenile court processing: inequality, the underclass, and social control," Law and Society Review, vol. 27, pp. 285-311, 1993.

[39] C. R. Tittle and D. A. Curran, "Contingencies for dispositional disparities in juvenile justice," Social Forces, vol. 67, no. 1, pp. 23-58, 1988.

[40] R. D. King and D. Wheelock, "Group threat and social control: race, perceptions of minorities and the desire to punish," Social Forces, vol. 85, no. 3, pp. 1255-1280, 2007.

[41] L. Bobo and J. R. Kluegel, "Status, ideology and dimensions of whites' whites' racial beliefs and attitudes: progress and stagnation," in Racial Attitudes in the 1990s: Continuity and Change, S. A. Tuch and J. K. Martin, Eds., pp. 93-120, Praeger, Greenwood, Conn, USA, 1997.

[42] L. Bobo, J. R. Kluegel, and R. A. Smith, "Laissez-Faire racism: the crystallization of a kinder, gentler, antiblack ideology," in Racial Attitudes in the 1990s: Continuity and Change, S. A. Tuch and J. K. Martin, Eds., pp. 15-41, Praeger, Westport, Conn, USA, 1997.

[43] E. Bonilla-Silva, White Supremacy and Racism in the Post-Civil Rights Era, Lynne Rienner Publishers, Boulder, Colo, USA, 2001.

[44] E. Bonilla-Silva and A. Lewis, "The new racism: racial structure in the United States, 1960s-1990s," in Race, Ethnicity, and Nationality in the United States, P. Wong, Ed., pp. 55-101, Westview Press, Boulder, Colo, USA, 1999.

[45] M. Kristen, Racetalk: Racism Hiding in Plain Sight, Roman and Littlefield, New York, NY, USA, 2005.

[46] E. Bonacich, "A theory of ethnic antagonism: the split labor market," American Sociological Review, vol. 37, no. 5, pp. 547559, 1972.

[47] M. Reich, Racial Inequality: A Political-Economic Analysis, Princeton University Press, New Jersey, NJ, USA, 1981.

[48] B. R. Wright, C. Avshalom, T. E. Moffitt, R. A. Miech, and P. A. Silva, "Reconsidering the relationship between SES and delinquency: causation but not correlation," Criminology, vol. 37, no. 1, pp. 175-194, 1999.

[49] S. F. Messner and R. J. Sampson, "The sex ratio, family disruption, and rates of violent crime: the paradox of demographic structure," Social Forces, vol. 63, no. 3, pp. 693-713, 1991.

[50] W. J. Chambliss, "Policing the ghetto underclass: the politics of law and law enforcement," Social Problems, vol. 41, pp. 177-194, 1994. 
[51] J. J. Savelsberg, "Knowledge, domination, and criminal punishment," The American Journal of Sociology, vol. 99, no. 4, pp. 911943, 1994.

[52] R. L. Engen and S. Steen, "The power to punish: discretion and sentencing reform in the war on drugs," The American Journal of Sociology, vol. 105, no. 5, pp. 1357-1395, 2000. 

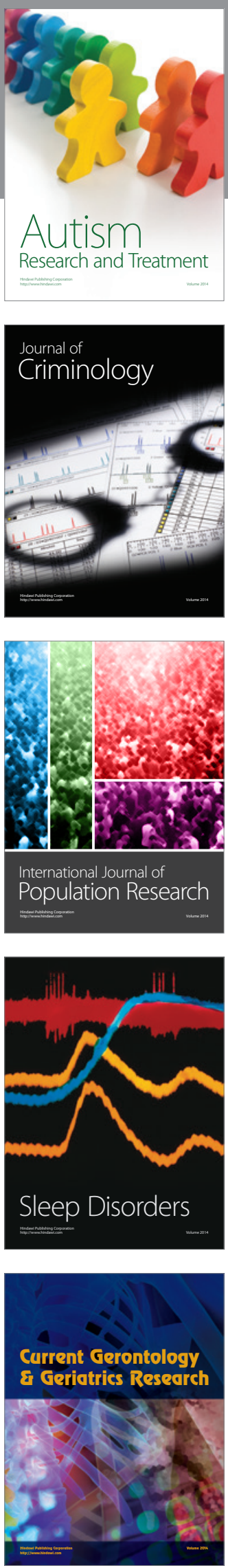
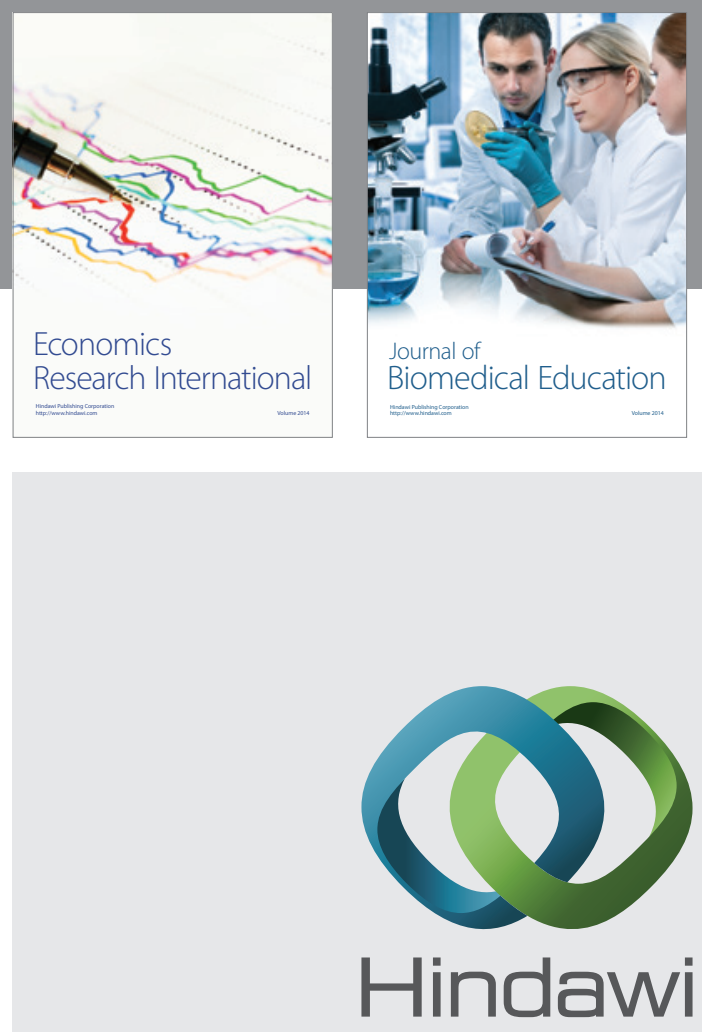

Submit your manuscripts at

http://www.hindawi.com
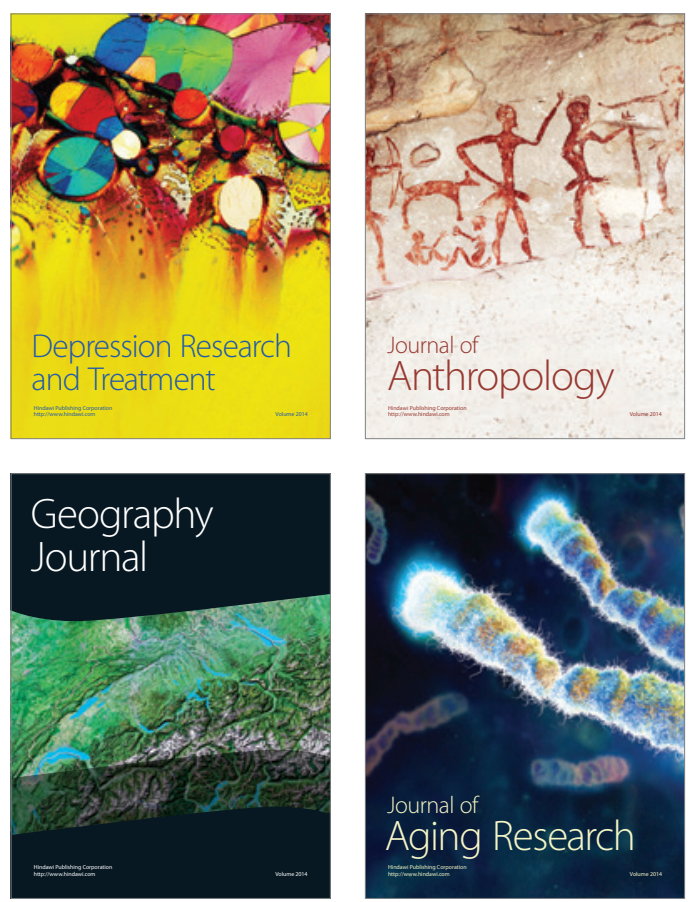
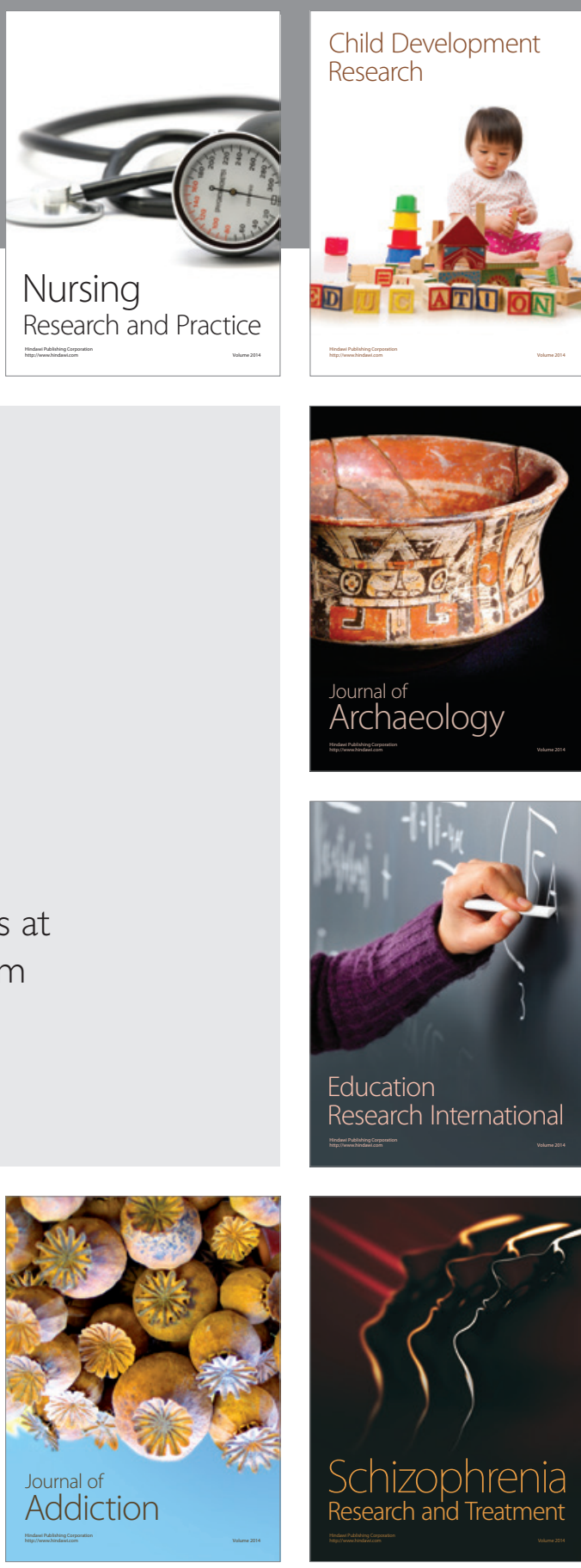

(D)
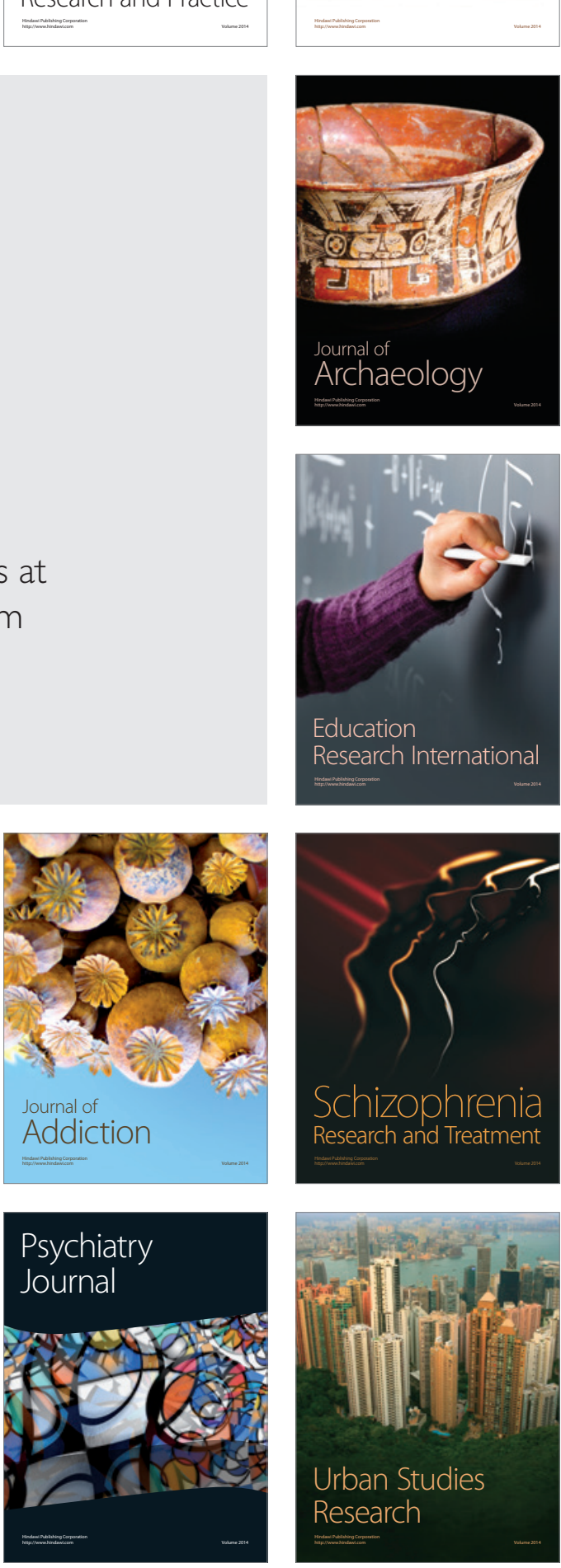